\title{
Islamic Epistemology Paradigm: Worldview of Interdisciplinary Islamic Studies Syed Muhammad Naqueb Al-Attas
}

\author{
Mahmudin ${ }^{1}$, Ahmad Zayyadi', Abdul Basit ${ }^{3}$ \\ ${ }^{1}$ Head Master of Islamic Senior Hight School 3 Cilacap \\ Cimanuk 09 Kroya Cilacap Central Java KP 53282 \\ e-mail:mahmudin19750617@gmail.com \\ ${ }^{2}$ Lecturer of Sharia Faculty, State Institute of Islamic Studies (IAIN) Purwokerto \\ Jl. A. Yani No. 40 A Purwokerto Central Java \\ e-mail:ahmedzyd@iainpurwokerto.ac.id \\ ${ }^{3}$ Professor of the Faculty of Da'wah, State Institute of Islamic Studies (IAIN) \\ Purwokerto Central Java \\ Jl. A. Yani No. 40 A Purwokerto \\ e-mail: abdulbasit@iainpurwokerto.ac.id
}

Article

History:

Submit:

2021-02-21

Publish:

2021-03-05
This article departs from the author's anxiety about Islamic epistemology vis a vis the Islamization of science in the worldview of interdisciplinary Islamic epistemology, Syed Muhammad Naqueb al-Attas regarding the Islamization paradigm of science with a concept with an approach based on the paradigm of Islamic epistemology. In this case, the problem of Islamization is fundamental epistemologically. However, al-Attas does not want to contradict one another, in fact, it further strengthens the Islamization of science under Islamic epistemology's spirit or values. The epistemology of Islamic thought of Syed Muhammad Naqueb al-Attas regarding the concept of epistemology vis a vis the Islamization of science is not only built on revelation and religious belief. However, it is built on a cultural tradition strengthened by philosophical speculation related to secular life that focuses on humans as rational beings. As a result, science and ethical and moral 
values, governed by human reason, are constantly changing. Syed Muhammad Naquib Al-Attas' Interdisciplinary Islamic Studies is a conception of the need for the Islamization of science related to reality and truth is understood by the unification method where there is a unity between inductive and deductive, empirical, and rational principles. The approach and theory used in this paper explore the historical roots of the epistemological paradigm of Syed Muhammad Naquib AlAttas by combining esoteric and ecstical elements as well as the combination of secularism and religion. However, it must be an interdisciplinary scientific discipline in Islamic studies.

Keywords: Paradigm, Islamic epistemology, Islamization of science, interdisciplinary, al-Attas

Journal Homepage http://ijssr.net/index.php/ijssr

This is an Open Access article under the CC BY SA license

https://creativecommons.org/licenses/by-sa/4.0/

Published by Indonesian Academy of Social and Religious Research

\section{Introduction}

The scientific theory currently developing shows the fact that there is a real divorce or "separation of beds" between science and religion. There is also an understanding that humans are the center of nature (anthropocentric), so the renaissance echoes loudly, echoing that "man can do all things they will" means that humans are free to do whatever they want. The impact is that Western civilization is so hegemonic that it causes science to have a secular (if not antireligious) face. In the view of Islam, knowledge is worship and an inherent part of religion. ${ }^{1}$ Throughout the history of human life, there have been many challenges and chaos that have been faced. However, they have never faced a complex and severe challenge as that posed by Western civilization today. ${ }^{2}$ Prof. Syed Muhammad Naquib al-Attas, a well-known thinker by the world of Western and Islamic thought, seems to bring our heads back to his senses and see that the most challenging problems facing humans today are the hegemony

Syed Muhammad Naquib al-Attas, Islam and Secularism, (Kuala Lumpur:ISTAC,1995), p. 134-137.

2 Ibid

Syed Muhammad Naquib al-Attas, Islam, Secularism, And the Philosophy of The Future,

(London \&New York: Mansell Publishing Limited, 1985), p. 127. 
and domination of Western secular science, which leads to the destruction of humanity. Syed Muhammad Naquib al-Attas stated;

"Many challenges have arisen during man's confusion throughout the edges, but none perhaps more serious and deconstructive to man than today's challenge posed by Western civilization." ${ }^{3}$

Today, the Western civilization based on secularism and materialism has brought the world to the threshold of destruction. Indeed, it does not turn a blind eye to the various successes and advancements produced by this civilization. Nevertheless, it is also undeniable that Western civilization has also played a significant role in producing colonization, prolonged war, social inequality, environmental damage, alienation (alienation), and anomie (reduced social customs or ethical standards in the individual or social line of society) so that there is no balance and order in society. Epistemology is a fundamental science, because it is directly related to science, justification, and the rationality of belief. Epistemology is part of philosophy. From this we can understand that epistemology becomes the path as well as the mother for Western sajrana to explore and understand something. More than that, epistemology becomes a means to build a comprehensive understanding with the meaning not just a gradual justification, but with empirical evidence and also using correct and authoritative critical reasoning. In the context of Islamic philosophy, epistemological thought is usually combined with the branches of traditonal scholarship ('ulüm an-naqliyah) and rational scholarship ('ulum an-'aqliyab). ${ }^{4}$ The other side of the continuation of irrational scholarship ('ulum al-m'arifah) understanding is the metaphysical approach. Metaphysics is still a branch of philosophy, where this science is a pathway for strengthening through in-depth analysis. ${ }^{5}$

In the context of the dialogue of Islamic epistemology as an interdisciplinary paradigm, there has not been much practice, especially concerning the interdisciplinary epistemological paradigm in Islamic studies conducted by Muhammad Naqueb Al-Attas, which is still rarely done. Al-Attas' paradigm is also a constructive leteary criticism in building an integrative, inter, and multidisciplinary paradigm in Islamic studies today.

3 Ibid

4 Sigit Tri Utomo, Nur Alfi Mu'anayah, "Epistemology of Islamic Education Al-Jabiri Perspective of the Conservative-Modernist-Neo Modernist Flow and Burhani-Bayani-Irfani", International Journal Ihya' 'Ulum al-Din, Vol. 22, No. 22, 2020, p. 167

5 Surajiyo, "Filsafat Ilmu Dan Perkembangannya Di Indonesia.," Freeink11 (blog), January 7, 2012, https://rachmatfatahillah.blogspot.com/2012/01/resume-filsafat-ilmu-dan.html. 


\section{Literature Review}

Dinar Dewi Kania wrote a dissertation by conducting library research using a comparative study method between Frithjof Schuon's Thought and Syed Muhammad Naquib al-Attas, resulting in several important implications for the philosophy of Islamic education, including the need to reformulate objectives. Islamic education that is transcendent and following the purpose of human life is to know Allah SWT and know the correct procedures for worshiping Him, so a holistic Islamic education curriculum is needed, covering those that are obligatory person and collection from elementary to college, because It is inevitable that the Islamization of contemporary science in the epistemological area must be pursued. Epistemology comes from the Greek episteme, which means knowledge (knowledge) ${ }^{6}$ Moreover, logos, which means science. Epistemology is a branch of philosophy that discusses science so that epistemology is also known as the philosophy of science or scientific theory. ${ }^{7}$

Epistemology discusses in detail and in-depth everything about the process seen in human efforts to acquire knowledge. ${ }^{8}$ Science is knowledge obtained through scientific methods, so this method is what distinguishes science from other ideas. ${ }^{9}$ Epistemology aims to analyze the process of gaining knowledge. Therefore, it must first trace where the process started and when it should end. ${ }^{10}$ Related to what has been built by Amin Abdullah and Mulyadi Kartanegara regarding the interdisciplinary epistemology building in the study of Islamic studies that in multidisciplinary, interdisciplinary and transdisciplinary studies are integrated into three fundamental religious matters, namely faith, Islâm and Ihsân. ${ }^{11}$ If we borrow the term Abied Al-Jabari, the integrated integration between bayânî, "irfânî, and burhanî is proportional. ${ }^{12}$ In the context of Syed Muhammad Naquib al-Attas, it is more aimed at building a constructivist paradigm inter and

6 Jonathan Ree (ed), The Concise Encyclopedia of Western Philosophy, $3^{\text {rd }}$ Edition, New York: Routledge, 2005 , p. $112-113$

7 Dinar Dewi Kania, Pemikiran Epistimologi Muhammad Naquib Al Attas \& Frithjof Schuon, (Gontor Ponorogo : UNIDA Gontor Press),p. 25

8 Ahmad Tafsir, Filsafat Ilmu; Mengurai Ontologi, Epistimologi, dan Aksiologi Pengetahuan, Cetakan Keempat, Bandung : Remaja Rosda Karya, 2009, hlm. 69.

9 Jujun Suriasumantri, Ilmu dalam Perspektif, Cet. Ke-17, (Jakarta : Yayasan Obor Indonesia, 2009), p. 9

10 Alparsalan Acikgenc, Scientific Thought, and Its Burden: An Essay in the History and Philosophy of Science, (Istanbul: Fatih University Yyinlari, 2000), p. 26

11 Amin Abdullah, Multidisiplin, Interdisiplin, E Transdisiplin: Metode Studi Agama E Studi Islam di Era Kontemporer, (Yogyakarta: IB Pustaka, 2020), p. 224-225.

12 Muhammad Abied Al-Jabiri, Takwîn al-'Aql al-'Arabî, (Beirut: al-Markaz ats-Tsaqafî al-Arabî), p. 34 In Indonesian Edition, Formasi Nalar Arab Kritik Tradisi Menuju Pembebasan dan Pliralisme Wacana Interreligius, Translator: Imam Khoiri (Yogyakarta: Ircisod, 2014), p. 200. 
multidisciplinary Islamic epistemology which is then followed by his students such as Osman Bakar, Farid al-Attas, Kamal Hassan and so on.

Therefore, the epistemological framework of Syed Muhammad Naqueb alAttas clearly states that the sources are derived from the thoughts of the Sufis who are able to provide a comprehensive metaphysical explanation. Al-Attas concludes with great confidence in his dissertation on Hamzah Fansuri - which inspired the emergence of the Islamic worldview integration or interdisciplinary paradigm - as follows.

"...that it through Sufism that the highly intellectual and rationalistic religious spirit entered the receptive minds of the people, effecting a rise of intellectualism and rationalism not manivested in pre-Islamic times...revolutionalizing the Malay- Indonesian worldview, turning it away from a crumbling world of mythology... to the world of intelligence, reason, and order; that it emphasized the belief in a God whose power is governed by wisdom, whose creative will works in accordance with reason; that it emphasized Man as the epitome of creation, whose very essence is rationality which is connecting link between him and Reality; that finally-to use a pregnant remark- it prepared the Malay-Indonesians, in a sense, for the modern world to come." ${ }^{13}$

For Syed Muhammad Naqueb al-Attas-as depicted in the works of Hamzah Fansuri-is considered to have succeeded in changing the worldview of people such as Indonesian-Malaysia which was previously full of mythology, both because of the influence of old beliefs and due to the influence of HinduBuddhist teachings that came recently, become an Islamic worldview. The eschatological acceptance by Syed Muhammad Naqueb al-Attas, even considered the main source in the process of Islamization of science, contradicts the concept of Reformism-Salafiyyah which tends to reject Sufism and claim it as one of the causes for the decline of Islam. ${ }^{14}$ In an interdisciplinary and multidisciplinary way, this paradigm must first Islamize metaphysics, a philosophical framework, and epistemology as value systems in the building of inter and multi disciplinary Islamic studies.

13 Syed Muhammad Naquib al-Attas, "The Concept of Education in Islam", Paper presented at the World Conference on Islamic Education in Mecca, (1997), p. 194-195. Wan Daud, The Educational Philosophy and Praktice Syed Muhammad al-Attas, (Kuala Lumpur: ISTAC, 1998), p. 295. Wan Daud, Filsafat dan Praktik Pendidikan Islam Syed M. Naquib al-Attas, (Bandung: Mizan, 2003), p. 321.

14 Wan Daud, The Educational Philosophy and Praktice Syed Muhammad al-Attas, (Kuala Lumpur: ISTAC, 1998), p. 296-297. 
Science is a product of the worldview of a nation, religion, culture, and civilization. This shows that there is a close relationship with society's values and beliefs or beliefs, so that science in this view (Islamic) is not value-free. The principles of Islamic epistemology need to be derived from the Islamic natural view (worldview) to obtain a framework of thought, which must be based on the Al-Qur'an, al-Hadith, and the Islamic intellectual tradition. This is where we find quite important data that Islamic epistemology does have a peculiarity that neither western epistemology nor any other civilization has ever had.

\section{Methodology}

This study uses a qualitative approach with a constructivist paradigm to understand how the Islamic Epistemological Paradigm, Interdisciplinary Islamic Natural View According to Syed Muhammad Nuqaeb Al Attas, Interpreting fundamental concepts in practical implementation is closely related to the world of Islamic thought. The concept of religion shows the intention of seeking knowledge and involvement in the educational process. The concept of human (insan) to scope. The concept of science 'ilm and ma'rifah refer to the content. The concept of wisdom is criticized in relation to the concept of man and knowledge. The concept of justice to development is concerning the concept of wisdom. The concept of right action to the method is related to the concept of religion, the concept of justice. The concept of kulliyah jami'ah is considered important because it functions as an implementation of all these concepts and becomes a model for the Islamic thought on epistemological system. ${ }^{15}$

A qualitative approach is an approach to building a knowledge based on a construction paradigm, such as entering meanings based on individual experience, social and historical values to build a particular theory or pattern, and based on a participatory perspective or both. Qualitative studiy aims to understand objects in depth (ideographically), not to find laws or make generalizations. ${ }^{16}$ Related to this construction paradigm, the writer wants to develop concepts and theories of science in a trans disciplinary and cross disciplinary way because this method is very relevant to the context of this article, namely transdisciplinary, it is hoped that it can provide resource-rich scientific benefits, while the cross disciplinary

15 Ibid.

16 Ibid. 
paradigm analyzes and discusses the concept of discipline. other sciences, into their own disciplines according to rational empirical experience. ${ }^{17}$

Therefore, data collection was carried out by tracing various literacies related to the thoughts of Syed Muhammad Nuqaeb Al Attas, both in the form of his work or writing about his thoughts, especially those that focus on Islamic epistemology and Islamic views of nature, both in the form of books, or scientific journals which is on national or international level.

\section{Result and Discusion}

In interdisciplinary Islamic epistimology, al-Attas covers the world of 'irfani or eschatological/sufistic. These mean that Sufism in the Malay-Indonesian world for Syed Muhammad Naqueb al-Attas-as depicted in the works of Hamzah Fansuri - is considered to have succeeded in changing the natural view (worldview) of society in this region, which was previously full of mythology, which is because of the influence of old beliefs and due to the effect of Hindu-Buddhist teachings that came recently, it became an interdisciplinary Islamic worldview. ${ }^{18}$ This is the best example of the Islamization process in the archipelago. The same thing happened when the Prophet Muhammad Islamized the Arabian Peninsula. The Arabic concepts that reflect the worldview of the Jahiliyyah Arabians are adjusted according to the Islamic teachings brought by the Prophet. Thus, the worldview that underlies the thought of the Arab nation to become Islamic as reflected in the meanings of its philosophical discussion.

The acceptance of the eschatological-sufistic context by Syed Muhammad Naqueb al-Attas, even considered the primary source in the process of Islamization of science, contradicts the concept of Reformism-Salafiyyah, which tends to reject Sufism, especially rationalists, and claim it as one of the causes for the decline of Islam. ${ }^{19}$ including traditional science is such as kalam, figh, tasawuf. They unlike islamic contemporary disciplines, which is in line with the Islamic worldview. In Islamic perspective, the contemporary sciences must first Islamize their metaphysics, philosophical framework, and epistemology, not

17 Noeng Muhajir, Metodologi Keilmuan: Paradigma Kualitatif, Kuantitatif, dan Mixed, Edition V, 2007, (Yogyakarta: Rake Sarasin, 2007), p. 16-17

18 Syed Muhammad Naquib al-Attas, "The Concept of Education.., p. 195-196. Wan Daud, The Educational Philosophy..., p. 295-296.

19 Wan Daud, Filsafat dan Praktik Pendidikan Islam Syed M. Naquib al-Attas, (Bandung: Mizan, 2003), p. 322 . 
suddenly Islamicize their methodology at a technical level. Suppose we refer to the actual conflict or contradiction between the West-Islam. In that case, it is not the methodology but the value system and the worldview, which includes issues of metaphysics, philosophy, and epistemology.

The concept of Islamization of science that is felt to be the most fundamental and touches the root of science problems is a concept with an approach based on the Islamic paradigm. The concept of Islamization was first systematically conveyed by Syed Muhammad Naqueb al-Attas. In fact, He specifically mentioned that the problem of Islamization is a fundamental problem of an epistemological nature. ${ }^{20}$ Thus, the paradigmatic concept of Islamization of science will be firmly rooted and following the classical Islamic tradition's psychological-philosophical values.

According to the Islamic perspective, the Islamization of science must be built on a metaphysical, philosophical, and epistemological framework that is correct. This basic framework must be understood well and clearly by Muslim scholars and scientists before applied in various disciplines, each of which is of various types. Therefore, every Muslim intellectual must understand their religion, have the right worldview of Islam, properly master the metaphysical framework of Islam, and continue to carry out the Islamization program of science. Metaphysics and Islamic worldview can only be obtained by understanding the Islamic scientific tradition itself. With the massive Islamization of science in the thoughts of Syed Muhammad Naqueb al-Attas, it is hoped that Islamic life in intellectual societies, especially in Indonesia, it will increase quality in producing a more progressive worldview and valuable for the scientific treasures of interdisciplinary Islamic studies. which developed until recently.

In Islamic epistemology, there is also a way to be able to know and understand natural phenomena. This contrasts with the Sophists' epistemology, who lived before Socrates, Plato, and Aristotle, who stated that man could not know anything. This group is mentioned in the works that discuss the faith ('aqa'id) as the group of "al-Sufasha'iyyah", as described by Syed Muhammad Naqueb alAttas below,

"In Islam, the sophistai became known as the sulfasta, and their various schools the sufasta'iyyah. Al-Baghdadi (d.103/78) was one of the earliest authorities to

20 Wan Daud, The Educational Philosophy and Praktice Syed Muhammad al-Attas, (Kuala Lumpur: ISTAC, 1998), p. 301. 
write about them and identify them into three groups. Al-Nasafi referred to them in the Aqa'id, and his commentator, al-Taftazani, mentioned the names of the three groups and gave a resume of their beliefs in his commentary. Al-Ranieri, deriving perhaps from the al-Taftazani's commentary, also mentioned the three groups in question, giving a brief exposition of their beliefs in his Tibyan. ${ }^{21}$

Then this pseudo-science group developed and materialized into various forms and forms and the typical tendencies of each, such as the al-inadiyyah, al'indiyyah, and al-la adriyyah. In this regard, Syed Muhammad Naqueb al-Attas explained in detail the appearance and existence of this group. He wrote,

"...The expression la adri means 'I do not know', and the la adriyyah are people who say that they do not know whether or nor a thing has real existence. They doubt the real existence of thing and are in doubt even of their own doubt. They are therefore people who deny the possibility of knowledge, and are properly called agnostics. As to the second appellation, the word 'indi' means 'according to me', or 'to my opinion'; and the 'indiyyah' are people who say that there is no objective truth in knowledge; all knowledge, they say is subjective, and the truth about anything is only one's opinion of it. In this sense they are epistemological Subjectivists. Finally, in the third goup called the 'indiyyah, which means 'the obstinate, they refer to people who deny the realities of things and maintain that what we call 'things' are mere fancies and figments of the imagination. In a sense the Obstinate are closer in ideas to the Subjectivists than the Agnostics, although in fact all the three groups have in common the denial of objective knowledge. ${ }^{22}$

Syed Muhammad Naqueb al-Attas put forward a more apparent paradigm of Islam as a religion based on revelation. According to him, Western scholars have found no more correct way to define religion except in terms of historicity due to the facts they find in Western Christianity. Even though it claims to be a religion based on revelation, many doctrines in Western Christianity that, according to early Christian sources, were not inspired by God, for example, the doctrine of the Trinity, redemption, incarnation, and all other dogma details related to it. Therefore, they understand that religion is part of culture and tradition or only

21 Syed Muhammad Naquib al-Attas, The Oldest Known Malay Manuscript.p. 24-25.

22 Ibid., p. 48-49. 
as a cultural product (muntâj al-Tsaqafî). ${ }^{23}$ which were created in history, evolved in history, and will always experience changes and "developments" in the times. ${ }^{24}$

The confusion regarding Christianity's status as a revealed religion is also evident in the law is adopted. It is a fact that Christianity does not have revealed legal rules (shari'a), which are revealed in the teachings, sayings, and examples of the works (sunnah) of the Prophet' Isa (peace be upon him), so this is an essential indication that Christianity is not a revealed religion, but rather religion formed by humans in history. Therefore, Christianity gradually developed its ritual system by adopting and absorbing other cultures and traditions and creating its ritual system. Gradually Professor al-Attas explained his religion's principles, such as what was done in Nicea, Constantinople, and Chalcedon. Since it had no revealed law, Christianity adopted and absorbed Roman laws. Moreover, in the absence of a solid worldview presented by its revelation, Christianity had to "borrow" the Greco-Roman worldview, and from it, they built their theological and metaphysical systems. ${ }^{25}$

Syed Muhammad Naqueb al-Attas also emphasized that Islam's intellectual, religious, and cultural traditions do not have the characteristics of an era characterized by the victory of thought based on materialism or idealism, with various positions such as empiricism, rationalism, positivism, criticism, and so on. The characteristics of the historical period in Islam also do not recognize classical, medieval, modern times and are now changing again to post-modern; or also the period of renaissance (rebirth) and enlightenment. The paradigm changes because it comes from philosophical and cultural elements. The system of thought and its value system do not solely come from cultural and philosophical elements assisted by science. However, its original source is revelation supported by reason and intuition. ${ }^{26}$

So, emphasized Syed Muhammad Naqueb al-Attas, Islamic epistemology has "matured" when it appears on the stage of world history. Islam does not require a process of "growth" to maturity. In other words, Islam does not require progressivity, development, and change in matters that are very clear and final.

23 Clifford Geertz, The Implementation of Cultures: Selected Essays, translator: F. Budi Hardiman, (Yogyakarta: Kanisius, cet. 9, 2003), see, Edi Mulyono, M. Ag., Belajar Hermeneutika, (Yogyakarta: IRCIsoD, 2012, cet. I), p. 225; see, M. Yusron, dkk., Studi Kitab Tafsir Kontemporer, ((Yogyakarta: TH-Press, 2006); Nasr Hamid Abu Zayd, Mafhum al-Nash: Dirasah fi 'Ulum al-Qur'an, (Beirut: al-Markaz al-Tsaqafiy al- 'Araby, 1994), p. 9

24 Syed Muhammad Naquib al-Attas, Islam and Secularism..., p. 26-27.

25 Ibid, p. 28-29.

26 Syed Muhammad Naquib al-Attas, Prolegomena to the Metaphysics of Islam..., p. 3-4. 
The so-called 'development' in the cultural-religious tradition cannot be applied to Islam because of the assumptions and explanations that must occur in generations of believers of different countries and refer to unchanging sources. ${ }^{27}$

The object of science in Islamic epistemology does not merely reach out to physical reality, but it also recognizes the ontological status of metaphysical things as things known by humans. The sources of knowledge in Islamic epistemology consist of (1) revelation, in the form of al-Qur' an and al-Sunnah, (2) 'aql (reason) and qalb (heart/heart), and (3) the five senses. Meanwhile, the process of gaining knowledge in Islam is closely related to the role of the human soul. It is obtained through several sources, namely: sense perception, common sense (ta'aqqul), and correct institutions and news (khabar sadiq). In Islamic epistemology, the revelations of good in the Koran and Sunnah are the highest knowledge sources. These revelations' scientific value is put in the right place and cannot be "divorced" from science or science. ${ }^{28}$ If examined historically, Syed Muhammad Naqueb alAttas' interdisciplinary Islamic thought paradigm is a thought that originated from metaphysics to the cosmological world and led to psychological. ${ }^{29}$

Syed Muhammad Naqueb al-Attas built his epistemology, adopting many of the views put forward by Imam al-Ghazalî (1058-1111 AD), especially in the book Ma'ârid which was derived from the books of Shifâ' and Najât by Ibn Sînâ (980-1037 AD). The interdisciplinary worldview of Islamic epistemology is limited to the physical world or human involvement from social, political, cultural, and historical aspects. However, it must also include aspects of the hereafter (ukhrawi). Because this aspect of the world must be closely related to the hereafter, this aspect must be placed as our goal and foundation for living in the world to guard against Muslims and humankind's intentions and perspectives as a whole. ${ }^{30}$ This is as defined by al-Attas as follows,

"The worldview of Islam is not merely the mind's view of the physical world and man's historical, social, political and cultural involvement in it. It is not based upon philosophical speculation formulated mainly from observation of the data of sensible experience, the world of created things... Thus, what is meant by 'worldview' according to the perspective of Islam is the vision of reality and truth

${ }^{27}$ Ibid., p. 3-4.

28 Dinar dewi Kania, Objek Ilmu dan Sumber-Sumber Ilmu..., p. 110.

29 Nur Hasan, "Kritik Islamic Werldview Syed Mubammad Naquib al-Attas Terbadap Western Worldview",Jurnal Studi KeIslaman MARAJI' Vol. 1, No.1, September 2014, p. 12. Al-Rasyidin dan Nizar, Filsafat Pendidikan Islam: Pendekatan Historis, Teoritis, dan Praktis, (Jakarta: Ciputat Press, 2002), p. 124.

30 Syed Muhammad Naquib al-Attas, Prolegomena to the Metaphysics of Islam, (Kuala Lumpur: ISTAC, 1995), p. 1 
that appears before our mind's eye revealing what existence is all about; for it is the world of existence in its totality that Islam is projecting. In another world, it is ru'yah al-Islam li al-Wujud. "31

Epistemologically and metaphysically, the description and interpretation of the facts or everything become a "harmonious identity" to the Islamic natural view's worldview. As has been defined by Professor al-Attas above, namely "the vision of reality and truth that appears before our mind's eye revealing what existence is all about" or insights into reality and truth that appear before our minds' reveal' something that exists. From this definition, three important contents can be used as a framework identity (frame of mind), namely the worldview is a machine or 'motor of movement' for social change, the basis of principles for understanding the nature of reality and principles for scientific activity. In the view of Syed Muhammad Naqueb al-Attas, intellectual confusion arises as a result of the prohibition and changes in the use of keywords that project the Islamic worldview that comes from revelation. Intellectual confusion has transformed into cultural and moral deterioration, which is a symptom of deteriorating religious knowledge, faith, and values. ${ }^{32}$

Professor al-Attas thinks that the solution to Muslims' problems is the Islamization of Science, namely the nomenclature of "Islamization of contemporary science" which is somewhat different from the concept of Islamization put forward by other scientists. ${ }^{33}$ Because according to him, initially, all knowledge existed in its Islamic form. However, along with the development of the times, the original form (fitrah) of knowledge gradually changes.

This change occurred simultaneously with the process of secularization of society that occurred in Europe, which several hundred later was exported and heralded to the Islamic world. The definition of secularization that Syed Muhammad Naquib Al-Attas thinks is the most appropriate is the definition given by a theologian from Holland, Coernelius Van Peursen, who once occupied the chair of philosophy at Leiden University. Van Peursen defined secularization

31 Syed Muhammad Naquib al-Attas, Prolegomena to the Metaphysics of Islam, (Kuala Lumpur: ISTAC, 1995), p. 1; See Adnin Armas, Westernisasi Dan Islamisasi Ilmu, INSISTS Saturday Meeting Paper for May 19 2007, p. 8, in Adian Husaini (ed), Islamic Worldview: Lecture Materials in the Post-Graduate Program of Islamic Education and Thought at Ibn Khaldun University.

32 Syed Muhammad Naquib al-Attas, Prolegomena to the Metaphysics of Islam, (Kuala Lumpur: ISTAC, 2005), p. 15.

33 Tiar Anwar Bachtiar, Respon Pemikiran INSISTS, p. 283 
as "the liberation of a person, first from religious control and then metaphysics of thought and language". ${ }^{34}$

In the view of Prof. Naquib al-Attas, modern Western science, projected through its worldview, is built on Western culture and civilization's intellectual and psychological visions. ${ }^{35}$ According to him, five factors animate Western culture and civilization. (1) The intellect is relied upon to guide human life; (2) Dualistic towards reality and truth; (3) Affirming aspects of existence that project a secular view of life; (4) Defending the doctrine of humanism; (5) Making drama and tragedy as dominant elements in the nature and existence of humanity. ${ }^{35} \mathrm{In}$ the view of Syed Muhammad Naqueb al-Attas, the westernization of science is the result of confusion and skepticism. The westernization of science has brought doubts and conjectures to the stage of scientific methodology. Not only that, but the westernization of knowledge has also made doubt a legitimate epistemological tool in science. According to him, the westernization of knowledge is not built on revelation and religious beliefs. However, it is built on a cultural tradition strengthened by philosophical speculation related to secular life that focuses on humans as rational beings. As a result, science and ethical and moral values, governed by human reason, are constantly changing.

Islam is both a religion and a civilization. Islam is not only spread because of the sword. Islam spread, controlled, and saved (Islamized) communities in the areas it occupied. In Islam, there is no known exploitation of natural resources to be brought to the area where Islam originated. There was no increase in wealth for the Arabian peninsula. There is no poverty due to the entry of Muslims into the area where they live. Areas controlled or saved by Muslims have become rich and prosperous. That is the character of Islamic civilization, which is very different from the exploitative Western civilization. ${ }^{36}$

After we have a deep understanding of Islam and the West's natural view or worldview, the new Islamization process can be carried out. Therefore, the methodology used by Syed Muhammad Naqueb al-Attas in the process of Islamization of present-day knowledge consists of two steps or processes that are interrelated. That is as follows:

34 Syed Muhammad Naquib Al-Attas, Islam dan Sekulerisme, (Bandung: Pustaka, 1981), p. 17.

35 Ibid.

36 Syed Muhammad Naquib al-Attas, Prolegomena to the Metaphysics of Islam, (Kuala Lumpur: ISTAC, 2005), p. 16-17. 
a. It isolates the key elements and concepts that make up Western culture and civilization (the five elements previously mentioned), and every field of modern science today, especially in the humanities. However, the natural sciences, physics, and application must also be Islamicized, especially in interpretations of facts and in the formulation of theories. According to Syed Muhammad Naqueb al-Attas, if it is not following the Islamic view of life, then the facts will not be true. In addition, and the modern sciences must be scrutinized. It includes methods, concepts, presuppositions, symbols, and modern science; along with empirical and rational aspects, and those that have an impact on values and ethics, the interpretation of the historicity of the science, the theoretical building of its knowledge, its presuppositions regarding the world, and the rationality of scientific processes, the theory of science about the universe, its classification, its limits, relations and its relation to other sciences as well as its relation to society must be examined carefully. ${ }^{38}$

b. Incorporate Islamic elements along with key concepts in each relevant field and current science. If the process is completed, then Islamization will free humans and magic, mythology, animism, national cultural traditions that are contrary to Islam, and then from secular control to reason and language. Islamization will free the human mind from doubt (syakk), suspected (dzann), and empty argumentation (mira') towards the belief in the truth about spiritual, intellectual, and material realities. Islamization will produce interpretations of contemporary science and secular ideology, meanings and expressions. ${ }^{37}$

The inclusion of these Islamic elements will then change the interpretation, forms, and conceptual values of the knowledge content. ${ }^{38}$ Then, Syed Muhammad Naqueb al-Attas also detailed and included some of the primary (fundamental) concepts of Islam that must be poured and embodied in every branch of knowledge studied by Muslims, ${ }^{39}$ as follows:

37 S.M.N. al-Attas, The Concept of Education, p. 43.

38 See Rahmad Yulianto dan Achmad Baihaki, "Islamisasi Ilmu Pengetahuan Dalam Perspektif Syed Muhammad Naquib al-Attas", Jurnal Studi Agama-Agama Al-Hikmah, Vol. 4, No. 1, Thn. 2018, p. 15.

39 Syed Muhammad Naquib al-Attas, Islam dan Sekularisme, (Bandung: Pustaka, 1981), p. 233. 
a. The concept of religion (Din), b. The concept of Human (Insan), c. he concept of science ("Ilm and $M a$ " rifah), d. The concept of wisdom (Hikmab), e. The concept of justice ('Adl), f. The concept of right action (Amal as adab), g. The concept of a university (Kulliyah-Jami'ah).

Interpreting the fundamental concepts above, Rahmad Yulianto and Achmad Baihaki explained that the practical application or implementation is closely related to the world of education. The concept of religion (din) shows the intention of seeking knowledge and involvement in the educational process. The concept of human (insan) to scope. The concept of science ('ilm and ma'rifah) refers to the content. The concept of wisdom (bikmah) to the criteria concerning the concept of human (insan) and science ('ilm and ma'rifab). The concept of justice ('adl) to development in relation to the concept of wisdom (bikmab). The concept of right action (amal as adab) to the method is related to the concept of religion (din), the concept of justice (' $a d l)$. The concept of a university (kulliyah jami'ah) is considered necessary because it functions as an implementation of all these concepts and becomes a model for the lower levels' education system. ${ }^{40}$

Syed Muhammad Naqueb al-Attas's version of the framework of Islamization of science explicitly states that the sources are derived from the Sufis's thoughts. The latter can provide adequate metaphysical explanations. Professor al-Attas concluded with great confidence in his dissertation on Hamzah Fansuri - which inspired the emergence of the idea of the Islamization of science - as follows.

"... that it through Sufism that the highly intellectual and rationalistic religious spirit entered the receptive minds of the people, effecting a rise of intellectualism and rationalism not manifested in pre-Islamic times...revolutionalizing the Malay-Indonesian worldview, turning it away from a crumbling world of mythology...to the world of intelligence, reason, and order; that it emphasized the belief in a God whose power is governed by wisdom, whose creative will works in accordance with reason; that it emphasized Man as the epitome of creation, whose very essence is rationality which is connecting link between him and reality; that finally-to use a pregnant remark- it prepared the Malay-Indonesians, in a sense, for the modern world to come". ${ }^{41}$

40 Rahmad Yulianto and Achmad Baihaki, "Islamisasi Ilmu Pengetahuan Dalam Perspektif Syed Muhammad Naquib al-Attas", Jurnal Studi Agama-Agama Al-Hikmah, Vol. 4, No. 1, Thn. 2018, p. 16.

41 Syed Muhammad Naquib al-Attas, The concept of Education in Islam, Paper, (1977), p. 194-195; Wan Daud, The Educational Philosophy and Practice Syed Mubammad Naquib al-Attas, (Kuala Lumpur: ISTAC, 1998), p. 295; Wan Daud, Filsafat dan Praktik Pendidikan Islam Syed M. Naquib al-Attas, (Bandung: Mizan, 2003), p. 321 
In the context of interdisciplinary Islamic epistemology, al-Attas also includes the world of 'irfani or eschatological/sufism. That is, sufism in the world of Malay-Indonesian for Syed Muhammad Naqueb al-Attas-as reflected in the works of Hamzah Fansuri-considered to have succeeded in changing the view of nature (worldview) communities in the region that had been filled with mythology, both because of the influence of beliefs long or because the influence of the Hindu-Buddhist teachings that came later, became an Islamic worldview interdisciplinary. This is the best example of the Islamization process in the archipelago. The same thing happened when the Prophet Muhammad Islamized the Arabian Peninsula. The Arabic language concepts that reflect the Arab Jahiliyyah society's worldview are adjusted according to the Islamic teachings brought by the Prophet. Thus, the worldview that underlies the thought of the Arab nation to become Islamic as reflected in the meanings of its philosophical discussion.

The acceptance of the eschatological-sufistic context by Syed Muhammad Naqueb al-Attas, even considered as the main source in the process of Islamization of science, contradicts the concept of Reformism-Salafiyyah, which tends to reject Sufism (especially rationalists) and claim it as one of the causes for the decline of Islam. ${ }^{94}$ including traditional sciences - such as kalam, fiqh, tasawuf - unlike contemporary disciplines - Islam, is in line with the Islamic worldview. This is also in Islamizing contemporary sciences must first Islamize its metaphysics, philosophical framework, and the epistemology of science, not suddenly Islamicize its methodology, which is at a technical level. Suppose we refer to the actual conflict or contradiction between the West-Islam. In that case, it is not the methodology but the value system and the worldview which includes issues of metaphysics, philosophy, and epistemology.

The concept of Islamization of science that is felt to be the most basic and touches the root of science problems is a concept with an Islamic paradigm approach. ${ }^{42}$ The concept of Islamization of knowledge like this was first systematically conveyed by Syed Muhammad Naqueb al-Attas. In fact, he specifically mentioned that the problem of Islamization is a fundamental problem of an epistemological nature. Thus, the concept of Islamization of science paradigmatically will be firmly rooted and in accordance with the psychologicalphilosophical values of the classical Islamic tradition.

42 Ismail Raji al-Faruqi, Islamization of Knowledge: General Principles and work Plan, (Virginia USA: IIIT, 1995), p. 23-29. 
According to the Islamic perspective, the Islamization of science must be built on a metaphysical, philosophical, and epistemological framework that is correct. This basic framework must be understood well and clearly by Muslim scholars and scientists before applied in various disciplines, each of which is of various shades, types, and kinds. Therefore, every Muslim intellectual must first understand their own religion, have the right worldview of Islam, properly master the Islamic metaphysical framework, and carry out the Islamization program of science. Metaphysics and Islamic worldview can only be obtained by understanding the Islamic scientific tradition itself.With the massive Islamization of science in the thoughts of Syed Muhammad Naqueb al-Attas, it is hoped that Islamic life in scholarly societies, especially in our beloved homeland, Indonesia, will increase in quality in producing a more progressive worldview and valuable for the scientific treasures of interdisciplinary Islamic studies. which developed until recently.

\section{Conclution}

In the interdisciplinary Islamic epistemology, Syed Muhammad Naquib AlAttas touches on various disciplines of religion, education, and science, including the most creative and best in the realms of contemporary Islamic thought that define, conceptualize, and describe the core, meaning, and content of Islamic values, as well as methods of Islamization of contemporary science, as well as systematic Islamic scientific formulations, philosophical, and rational then. All of these ideas are fundamental to reviving the religious sciences, which Imam alGhazali attempted to achieve 900 years ago and is also an intelligent and brilliant, sophisticated effort is facing the scientific hegemony of modern secular Western civilization for future civilization Integrative, multi, and interdisciplinary Islam in responding to the challenges of modernity.

Syed Muhammad Naquib Al-Attas' Interdisciplinary Islamic Epistemology shows that the Islamic Worldview explain various disciplines of religion, education and science including the most creative and best in contemporary Islamic thought that defines, conceptualizes, and describes the content of Islamic values, and also the methods of Islamization of contemporary science, which is systematic, philosophical, and rational Islamic scientific formulations. All of these ideas are fundamental. We really need to revive the religious sciences to face the scientific hegemony of modern secular Western civilization to welcome the presence of an integrated, multi, and interdisciplinary Islamic civilization in responding to 
the challenges of modernity. This article provides a scientific contribution in the form of an awareness of Muslims' thinking to reconstruct Islamic education, which is firmly rooted in scientific foundations based on Islamic epistemology extracted from original Islamic sources, namely the Quran and Sunnah and their philosophical reflections, Al-Attas has brought revitalization. In mapping the renewal of contemporary Islamic thought.

\section{REFERENCES:}

Amin Abdullah, Multidisiplin, Interdisiplin, E' Transdisiplin: Metode Studi Agama E Studi Islam di Era Kontemporer, (Yogyakarta: IB Pustaka, 2020).

Abdur Rahnman Haji Abdullah, Pemikiran Islam di Malaysia: Sejarah dan Aliran, (Jakarta: Gema Insani Press, 1997).

Adnin Armas, "Wacana Metafisika al-Attas", Jurnal Pemikian dan Peradaban Islam ISLAMIA, Vol. XI, No. 2, Agustus, 2017.

Ahmad Tafsir, Filsafat Ilmu: Mengurai Ontologi, Epistimologi, dan Aksiologi Pengetahuan, Cetakan Keempat, Bandung : Remaja Rosda Karya, 2009).

Akhmad Rofi'i Damyati, "Makna dan Hakikat Wujud Dalam Pemikiran alAttas", Jurnal Pemikiran dan Peradaban Islam ISLAMIA, Vol. XI, No. 2, Agustus 2017.

Alparsalan Acikgenc, Scientific Thought, and Its Burden: An Essay in the History and Philosophy of Science, Istanbul: Fatih University Yyinlari, 2000).

Al-Rasyidin dan Nizar, Filsafat Pendidikan Islam: Pendekatan Historis, Teoritis, dan Praktis, (Jakarta: Ciputat Press, 2002).

Budi Handrianto, Islamisasi Sains: Sebuah Upaya Mengislamkan Sains Barat Modern, (Jakarta: Pustaka Al-Kautsar, 2007).

Clifford Geertz, The Implementation of Cultures: Selected Essays, penerjemah F. Budi Hardiman, (Yogyakarta: Kanisius, cet. 9, 2003)

Dinar Dewi Kania, "Pemikiran Epistemologi al-Attas", Jurnal Pemikian dan Peradaban Islam ISLAMIA, Vol. XI, No. 2, Agustus, 2017.

Dinar Dewi Kania, Pemikiran Epistimologi Muhammad Naquib Al Attas \& Frithjof Schuon, (Gontor Ponorogo : UNIDA Gontor Press).

Edi Mulyono, Belajar Hermeneutika, (Yogyakarta: IRCIsoD, 2012, cet. I)

Hamid Fahmy Zarkasyi, "Islam sebagai Pandangan Hidup", dalam Tantangan Sekularisasi dan Liberalisasi di Dunia Islam, ed. Tim KB Press (Jakarta: Khairul Bayan, 2004). 
,Al-Ghazalis Concept of Causality; With Reference to His Interpretations of Reality and Knowledge, terj. Burhan Ali \& Yulianingsih Riswan, Kausalitas Alam atau Tuban? Membaca Pikiran Religio-Saintifik al-Ghazali, (Ponorogo: UNIDA Gontor Press, 2018).

Imam Muhammad ibn 'Ali ibn Muhamad as-Syaukani (w. 1255 H), Irsyad al-Fubul Ild Tahqiq al-Haqqim 'Ilmi al-Ushul, (Beirut: Dar al-Kotob al'Ilmiyyah, 1994).

Ismail Raji al-Faruqi, Islamization of Knowledge: General Principles and work Plan, (Virginia USA: IIIT, 1995).

Jonathan Ree (ed), The Concise Encyclopedia of Western Philosophy, $3^{\text {rd }}$ Edition, New York: Routledge, 2005).

Jujun Suriasumantri, Ilmu dalam Perspektif, Cet. Ke-17, Jakarta : Yayasan Obor Indonesia, 2009).

Lihat Nur Hasan, "Kritik Islamic Werldview Syed Mubammad Naquib alAttas Terbadap Western Worldview", Jurnal Studi KeIslaman MARAJI' Vol. 1, No. 1, September 2014.

Lorens Bagus, Kamus Filsafat, (Jakarta: Gramedia Pustaka Utama, 2005, Cet. 6).

M. Yusron, dkk., Studi Kitab Tafsir Kontemporer, (Yogyakarta: TH-Press, 2006)

Mohammad Nasrin Nasir \& Malki Ahmad Nasir, Sains Islam, hlm. 20 mengutip al-Attas \& Wan Daud, 2007.

Muhammad Abied Al-Jabiri, Takwin al-Aql al-'Arabî,, (Beirut: al-Markaz atsTsaqafî al-Arabî).

Formasi Nalar Arab Kritik Tradisi Menuju Pembebasan dan Pliralisme Wacana Interreligius, Alih Bahasa: Imam Khoiri (Yogyakarta: Ircisod, 2014).

Nasr Hamid Abu Zayd, Mafhum al-Nash: Dirasah fi 'Ulum al-Qur'an, (Beirut: al-Markaz al-Tsaqufiy al- 'Araby, 1994).

Noeng Muhajir, Metodologi Keilmuan: Paradigma Kualitatif, Kuantitatif, dan Mixed, Edition V, 2007, (Yogyakarta: Rake Sarasin, 2007).

Nur Hasan, "Kritik Islamic Worldview Syed Mubammad Naquib al-Attas Terbadap Western Worldview”, Jurnal Studi KeIslaman MARAJI' Vol. 1, No. 1, September 2014.

SMN al-Attas, The Worldview of Islam, An Outline, Opening Adress", Dalam Sharifah al-Attas (ed.), Islam and the Challenge of Modernity, Proceeding of 
the Inaugural Symposium on Islam and the Challenge of Modernity: Historical and Contemporary Context, Kuala Lumpur August, 1-5, 1994, (Kuala Lumpur, ISTAC, 1996).

Sigit Tri Utomo, Nur Alf Mu'anayah, "Epistemology of Islamic Education Al-Jabiri Perspective of the Conservative-Modernist-Neo Modernist Flow and BurhaniBayani-Irfani', International Journal Ibya' 'Ulum al-Din, Vol. 22, No. 22, 2020

Syed Muhammad Naquib al-Attas, Islam and Secularism, (Kuala Lumpur: ISTAC, 1995). , Islam dan Sekulerisme, (Bandung: pustaka, 1981).

, Islam the Concept of Religion and the Foundation of Ethics and Morality, (Kuala Lumpur: IBFIM, 2013). , Islam, Secularism, And the Philosophy of The Future, , Prolegomena to the Metaphysics of Islam, (Kuala Lumpur: ISTAC, 1995). 2005). , Prolegomena to the Metaphysics of Islam, (Kuala Lumpur: ISTAC, , The Oldest Known Malay Manuscript, (London \&New York: Mansell Publishing Limited, 1985). , "The Concept of Education in Islam", Paper presented at the World Conference on Islamic Education in Mecca, (1997)

Wan Daud, The Educational Philosophy and Praktice Syed Muhammad al-Attas, (Kuala Lumpur: ISTAC, 1998)

, Filsafat dan Praktik Pendidikan Islam Syed M. Naquib al-Attas, (Bandung: Mizan, 2003). 